\title{
Sobre a Editoração Científica no Brasil e seu Crescimento
}

\author{
Harley E. A. Bicas, Paulo Elias C. Dantas, Mauro Campos, Cristina Muccioli, Claudia Moral
}

O crescimento da produção científica brasileira, tanto em quantidade, quanto em qualidade, é um fato notável, principalmente nos últimos anos. Na classificação mundial do número de publicações apresentadas por país, saltamos, recentemente, do $17^{\circ}$ lugar, em 2005, para o $15^{\circ}$ em 2007 , com um total de 16.782 artigos científicos $(1,92 \%$ da produção científica mundial), ficando à frente de países como Suécia, Suíça, Bélgica, Áustria e Polônia, tradicionais produtores de ciência; e já encostando na Rússia. Com os Arquivos Brasileiros de Oftalmologia, por exemplo, passamos de 78 publicações (58 artigos originais, 9 relatos de casos e 11 atualizações continuadas) em 2000 a 181 em 2007 (122 artigos originais, 49 relatos de casos e 10 atualizações continuadas). Claro que, simultaneamente, aumentou o número de oftalmologistas e, pois, o de autores potenciais. Mas o crescimento da classe, ainda que muito discutido, não é a única explicação. No mesmo período, quando o crescimento das publicações foi de $132 \%$ (!), o de oftalmologistas foi de (aproximadamente) 46\%, enquanto a população brasileira aumentou $13 \%$.

Assim, outros fatores devem ser admitidos como determinantes dessa ocorrência. Em primeiro lugar, o de uma inequívoca demanda por profissionais academicamente qualificados, leia-se, com títulos de Mestre e, ou Doutor, para preenchimento de postos de ensino (e, teoricamente, pesquisa), nas várias Faculdades que se abriram e continuam se abrindo no Brasil. Para o que, a cuidadosa preparação das respectivas dissertações e teses, geralmente proporciona trabalhos de bom nível científico. É justamente para isso que estão aí montados os cursos e todo nosso sistema de pós-graduação acadêmica ("sensu stricto"), privilegiando a formação de pesquisadores e professores universitários.

O segundo elemento é a forma como o desempenho acadêmico das pessoas já pertencentes às Universidades e centros de especialização profissional vem sendo valorizado pelas agências de fomento científico, que apóiam esses pesquisadores e seus trabalhos, e pelas próprias instituições às quais eles se ligam. Para tais órgãos, o reconhecimento da produção se dá, muito enfaticamente, sobre as publicações realizadas, não apenas em número, mas, sobretudo, por critérios de prestígio do veículo no qual elas aparecem.

Revistas científicas passam, então, a receber estamentos e classificações, como avalistas da qualidade do trabalho publicado. Essa demanda por melhores julgamentos tem, obviamente, impulsionado a editoração científica brasileira a um aperfeiçoamento de suas revistas. Nos últimos quatro anos, o número de revistas brasileiras inseridas na Scientific Electronic Library Online (SciELO) passou de 131 (em 2003) a 166 (em 2007)...
Cada um no seu papel: agências reguladoras e universidades estabelecendo critérios para pontuar progressos acadêmicos, revistas científicas agindo como mensageiras dessas valorizações e pesquisadores buscando suas publicações, precisamente, nessas boas revistas, para, assim, completar a ciranda...

Melhores publicações são mais procuradas, podem selecionar, "apenas", os artigos "super-excelentes", deixando os "somente" excelentes para as demais. Aqueles artigos, provavelmente, serão os mais lidos e citados, mantendo o chamado "fator de impacto" dessa revista (o critério tido como fundamental para qualificação das publicações) em nível elevado. Fecha-se, desse modo, um círculo vicioso: quem está fora não entra, quem está dentro não sai... As revistas com fatores de impacto menores (artigos "apenas" excelentes?), ou as sem suas medições (artigos "apenas" ótimos?), ou as ainda menos qualificadas (veiculando artigos "apenas" bons?) tendem a permanecer em seus escalões, pela própria dinâmica do processo.

Ora, regramentos são convenientes como fatores de orientação e as objetivações podem ter suas razões. Mas seria perfeitamente compreensível que alguém optasse por não se hospedar em um hotel "cinco estrelas", para ficar num de quatro, se este fosse de seu filho, um ato de apoio a que, precisamente por ele, se propiciassem condições de ascensão de suas qualidades e estrelas. Está aí o ponto que merece ser discutido. Não a natureza e valor das preferências explícita e escancaradamente dadas por nossas agências de fomento científico e Universidades a periódicos já consolidados e que, em sua quase totalidade, são estrangeiros. Mas o de que, com elas, condenam-se as publicações nacionais a situações constrangedoras e perversas, como as de chefes de serviço, orientadores de trabalhos acadêmicos e, até, os próprios editores dessas nossas revistas, resolverem que a publicação de seus artigos, ou aconselharem que a divulgação do que melhor por aqui se faz, seja canalizada a revistas (estrangeiras) de "alto impacto", para as pontuações acadêmicas devidas. É como se a divulgação (hoje garantida pela rede mundial de computadores, por veículos já selecionadores como os da SciELO, PubMed e outros) não fosse o mais importante.

Certamente, a editoração nacional, sem perda da pressão por melhoria de seus padrões (salutar!), seria mais beneficiada se fatores de incentivo ao seu crescimento fossem reconhecidos. É o que os hoje líderes da ciência mundial fizeram no início do século $\mathrm{XX}$, provincianos que foram e não globalizados, ao publicarem em suas revistas, não nas de fora, que eram consideradas melhores e que poderiam com elas concorrer.

Quem sabe? Um dia chegaremos a essa compreensão... 